\title{
Influence of UV Treatment on the Food Safety Status of a Model Aquaponic System
}

\author{
Sai Deepikaa Elumalai ${ }^{1}$, Angela M. Shaw ${ }^{1, *}$, D. Allen Pattillo ${ }^{2}$, Christopher J. Currey ${ }^{3}$, \\ Kurt A. Rosentrater ${ }^{4}$ and Kun Xie ${ }^{4,+}$ \\ 1 Department of Food Science and Human Nutrition, Iowa State University, Ames, IA 50011, USA; \\ deepikaa2c@yahoo.co.in \\ 2 Department of Natural Resource Ecology and Management, Iowa State University, Ames, IA 50011, USA; \\ pattillo@iastate.edu \\ 3 Department of Horticulture, Iowa State University, Ames, IA 50011, USA; ccurrey@iastate.edu \\ 4 Department of Agricultural and Biosystems Engineering, Iowa State University, Ames, IA 50011, USA; \\ karosent@iastate.edu (K.A.R.); xie@iastate.edu (K.X.) \\ * Correspondence: angelaml@iastate.edu; Tel.: +1-515-294-0868; Fax: +1-515-294-8181 \\ + Author is no longer with Iowa State University.
}

Academic Editors: M. Haïssam Jijakli and Ranka Junge

Received: 12 September 2016; Accepted: 21 December 2016; Published: 6 January 2017

\begin{abstract}
Few microbial studies in aquaponics, a growing trend in food production, have been conducted to determine food safety status. The aim of this study was to determine the food safety status and the effectiveness of ultraviolet treatment ( $15 \mathrm{~W}$, luminous flux of $900 \mathrm{~lm}$ ) as a food safety intervention in reducing the microbial loads of the water system in a model aquaponic unit growing lettuce, basil, and barramundi (Australian Sea Bass). Sweet basil, bibb lettuce, water samples, and fish swabs were collected throughout the 118-day production period, and microbial analysis was conducted in triplicate for the presence of E. coli O157:H7, Salmonella spp., and the prevalence of aerobic plate counts (APC), coliforms, and fecal coliforms in these systems. Absence of foodborne pathogens was confirmed using ELISA technology and enumeration through petrifilms (coliform/E. coli). A significant increase was observed in aerobic plate counts over the trial period ( 1 to $3 \log _{10} \mathrm{CFU} \cdot \mathrm{mL}^{-1}$ ) in the presence and absence of UV ( $\left.p>0.05\right)$. Ultraviolet treatment did not significantly reduce the APC or coliform counts when compared to the control system samples. Future work should focus on improving the unit design, the evaluation of bio-solid filtration, and other food safety interventions.
\end{abstract}

Keywords: aquaponics; barramundi; basil; food safety; lettuce; recirculating aquaculture systems; ultraviolet treatment

\section{Introduction}

In 2015, 163,675 growers and farmers were reported to be marketing foods locally [1]. The local foods movement has encouraged growers and farmers to diversify their farming practices and find additional market opportunities to expand their business. An increasingly popular method for farm diversification is aquaponics, which is an agricultural practice that involves the cultivation of crops in soilless (hydroponic) systems by fertilizing plants with nutrient-rich water from intensively cultured aquatic organisms such as fish [2]. There are many benefits to aquaponic crop production when compared to conventional soil culture such as accelerated plant growth [2], decreased production area requirements [3], reduced water usage [2], reduced environmental effluents [2], reduced system production costs [2], extended production season [4], reduced soil-borne plant pathogens [4], and diversification of farm products [5]. 
Between 1998 and 2008, 46\% of all foodborne illnesses reported were associated with fruits, vegetables, and nuts [6]. Food safety is an increasingly important concern in the food supply globally, and very few food safety interventions within an aquaponics system are known. A main food safety concern with aquaponics is the cultivation of fruit and vegetable crops in water containing fish excreta and other organic matter including fish and plant particulate residuals. E. coli O157:H7, Salmonella, and Listeria monocytogenes are the main foodborne pathogens that can be within the recirculating water system and have been shown to survive in these conditions [7,8]. Additionally, fish from non-reliable sources can introduce foodborne viruses and disease (e.g., Vibrio spp.) that are not commonly associated with fruits and vegetables [9].

Food safety concerns related to aquaponics have emphasized the need for more research in food safety interventions such as UV-treatment [10], ozonation [11], and organic acids [12]. The usage of ultraviolet light (UV-C) treatment in recirculating aquaculture has been suggested to reduce pathogen loads [13] in the water column, without adding any chemicals into the water, thus maintaining fish health and decreasing the need for water exchange [4]. Research with lettuce and UV treatment at $300-500 \mathrm{~W} \cdot \mathrm{s} \cdot \mathrm{m}^{-2}$ showed total coliforms counts below $1 \mathrm{CFU} \cdot \mathrm{g}^{-1}$ and a reduction in microbial loads higher than $99 \%$ with no significant difference in the productive traits of lettuce [10]. In 1985, UV irradiation was shown to inactivate bacteria Escherichia coli, Salmonella typhi, Shigella sonnei, Streptococcus faecalis, Staphylococcus aureus, Bacillus subtilis spores, viruses poliovirus type 1, simian rotavirus SA11, the cysts of the protozoan Acanthamoeba castellanii, as well as total coliforms and standard plate count microorganisms in effluent waste water at different intensities [14]. This suggests that use of UV treatment in aquaponics could be a valid method to produce vegetables with high hygienic standards. The purpose of this study was to determine the current food safety status in an aquaponic system and how effective UV treatment would be as a food safety intervention.

\section{Materials and Methods}

\subsection{Aquaponics Unit Design}

The six aquaponics units were identical with respect to the same ratio of plants, water, and fish as a commercial unit [15]. There were three independent experimental units (systems) for each treatment. Each system consisted of a fish culture tank, solids filtration, biological filtration, a deep water hydroponic culture unit, an ultraviolet sterilizer, a submersible magnetic drive centrifugal pump, and a diaphragm style aerator with eight $15 \mathrm{~cm}$ air stones per system (Figures 1 and 2). The water source of Ames, Iowa, used here was hard $\left(\sim 300 \mathrm{mg} \cdot \mathrm{L}^{-1}\right)$, with low to moderate alkaline concentrations (20-100 $\left.\mathrm{mg} \cdot \mathrm{L}^{-1}\right)$ and a basic $\mathrm{pH}$ of 8.8-9.4). It had a temperature between 14 and $18^{\circ} \mathrm{C}$, and contained chloramine as a microbial deterrent. The fish tank and solids/biofiltration tanks were $114 \mathrm{~L}$ high density polyethylene (HDPE) cone bottom tanks measuring $69 \mathrm{~cm}$ deep to the cone and $97 \mathrm{~cm}$ deep overall and a $45 \mathrm{~cm}$ diameter with a $45^{\circ}$ conical bottom. The $760 \mathrm{~L}$ deep water hydroponic units consisted of a metal constructed frame, measuring $1.2 \mathrm{~m}$ wide, $2.4 \mathrm{~m}$ long, and $0.3 \mathrm{~m}$ deep, that was insulated with TekFoil (TEK Supply, Dyersville, IA, USA), a 3.8-cm-thick polystyrene insulation covered reflective bubble wrap, lined with a $12 \mathrm{~mm}$ rubber liner. The pumps used were $2082 \mathrm{~L} \cdot \mathrm{h}^{-1}$ ActiveAqua Pumps (Grand Prairie, TX, USA) operated without pre-filters. Water was pumped through ValuTek, black braded utility hose that was $2.5 \mathrm{~cm}$ in diameter into the UV sterilizers. The UV sterilizers were TMC Vecton brand (Grants Pass, OR, USA) with a $15 \mathrm{~W}$ light (luminous flux of $900 \mathrm{~lm} / 432.6 \mathrm{~W} \cdot \mathrm{s} \cdot \mathrm{m}^{-2}$ ) output and rated for a $20.8 \mathrm{~L} \cdot \mathrm{min}^{-1}$ flow rate. This was recommended by the manufacturer based on flow rate, turnover, and size of the water system. Our flow rate of $20.8 \mathrm{~L} \cdot \mathrm{min}^{-1}$ fell under the $33 \mathrm{~L} \cdot \mathrm{min}^{-1}$ maximum recommended for the Vecton $15 \mathrm{~W}$ with a turnover that was within 1.5 times per hour. 


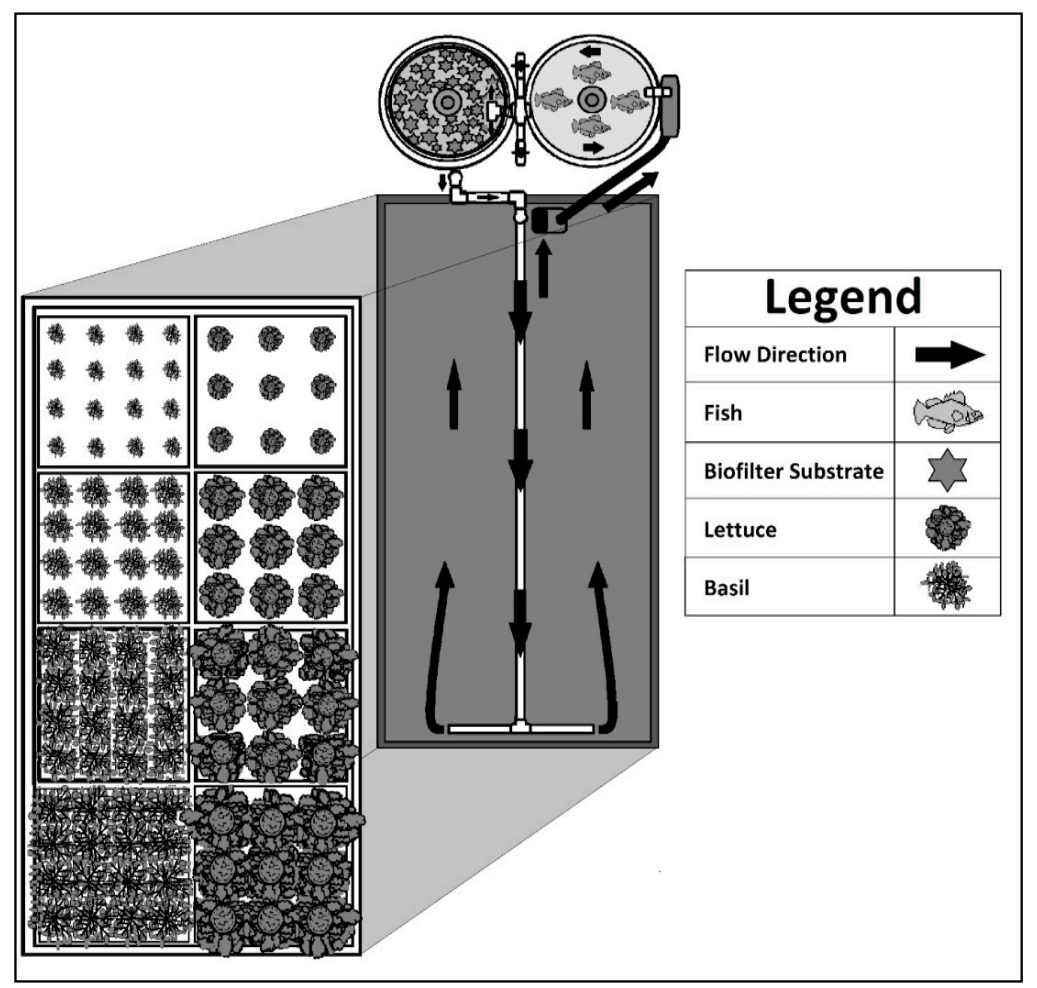

Figure 1. Overview of the total unit in the Iowa State University model aquaponic system utilized to grow lettuce, basil, and Barramundi.

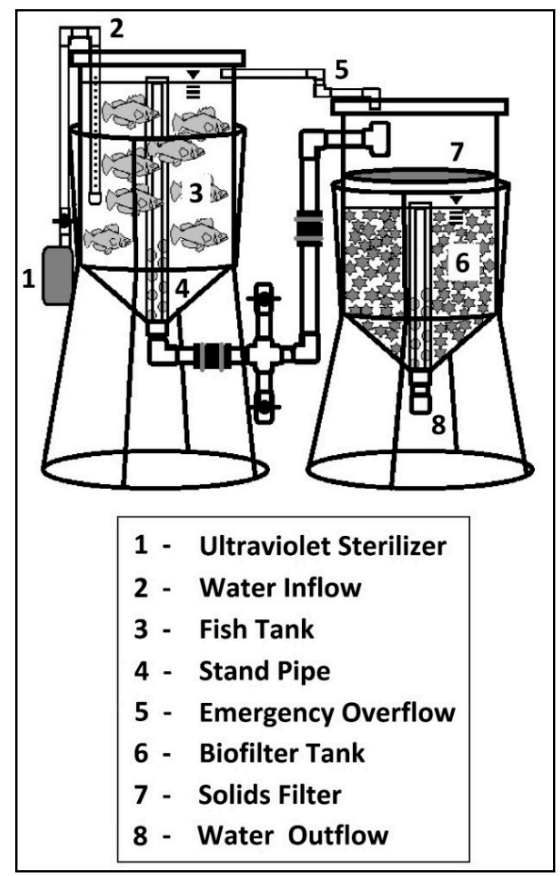

Figure 2. Diagram of the parts (i.e., UV sterilizer, water inflow, fish tank, stand pipe, emergency overflow, biofilter tank, solids filter, and water outflow) of the aquaculture unit utilized to house the Barramundi over 118 days for reproducibility of unit design.

The UV system was located after the hydroponic unit so that UV would act on water after sufficient nutrients were taken up by the plants, thus reducing particles in the water. The addition of a filter prior 
to the UV system may be recommended if dirt or large particles are within the water. We found that the turbidity of the water was between 1 and 2.5 NTUs, which is clearer than water that passes through a 50 micron filter (typically 20 NTUs; data not presented). Based on these data, we did not utilize a filter prior to the UV treatment. Water flow rate into the fish tank was adjusted with a PVC ball valve. Directional water inflow into the fish tank was created using a $50 \mathrm{~cm}$ section of a 2.5 -cm-diameter PVC pipe that was capped on the end. The water flowed out of 15, 6.4-mm-diameter holes drilled along a single plane to create a counter clockwise flow. A dual standpipe was created with $81-\mathrm{cm}$-tall section of 3.8-cm-diameter PVC pipe as a stand pipe and an 84-cm-tall external standpipe with holes cut in the bottom of it surrounding the standpipe. Two $15 \mathrm{~cm}$ air stones provided aeration and gas exchange in the fish culture tank. The water flowed by gravity into the mechanical filter screen, which consisted of $80 \%$ cover shade cloth that is 4 layers thick, then through an additional solids filter pad.

The biofilter was located directly below the mechanical filter screens and was filled with bio-balls, bio-barrels, and blocks of filter pad to provide an adequate surface area to harbor nitrogen-processing bacteria. The water depth in the biofilter was $51 \mathrm{~cm}$, and constructed in the same manner as the fish tank. Two air stones were located in the biofilter tank to provide mixing and aeration. The water then flowed by gravity to the far end of the deep water hydroponic unit through a 3.8-cm-diameter PVC pipe with a tee at the end to then be exposed to the plants. Four air stones were located in each hydroponic unit. The water slowly flowed back to the opposite end of the hydroponic unit into the pump, which then completed the circuit. We performed a dye test before the study began to ensure uniform water circulation in the system. To establish the biological filtration system, four bio-barrels were added to each of the six replicated systems from a pre-established system to enhance their biological filtration performance. After a period of 4 weeks, water chemistry testing indicated that nitrifying bacteria populations had been established in each system and it was safe to add the fish.

\subsection{Fish and Experimental Design}

Juvenile barramundi (Lates calcarifer) were obtained from a local aquaculture nursery (Blairsburg, IA, USA). Upon arrival, the fish were acclimated to laboratory conditions for 18 days prior to the first sampling date and were fed with a Ziegler brand Finfish G 42-16 (Gardners, PA, USA) floating diet with a $2.5 \mathrm{~mm}$ diameter containing $42 \%$ proteins and $16 \%$ lipids. The experiment was conducted during the winter, from November 2014 to January 2015. At the beginning of the experiment, 10 fish with an average weight of 120-165 g were stocked in each of the six fish culture tanks. Each experimental treatment (UV treatment and control) was replicated three times with three independent units per treatment. The fish were fed twice daily at 8:00 and 18:00 h over the 118-day experiment. The daily feeding rate was about $3 \%$ of the total body weight or until the fish showed signs of satiation. Excess feed was removed. A daily record was kept of the feed offered. A $16 \mathrm{~h}$ photoperiod was maintained throughout the experiment by using the $400 \mathrm{~W}$, high pressure sodium lamps from 06:00 to 22:00 $\mathrm{h}$ throughout the experiment.

Water temperature, dissolved oxygen, and $\mathrm{pH}$ were monitored daily using an HQ0d water quality probe ( $\mathrm{HACH}$, Ames, IA, USA). Water chemistry parameters were measured either once (alkalinity, hardness, carbon dioxide, chloride, iron) or twice (ammonia, nitrite, nitrate) weekly. The recommended levels were as follows: $\mathrm{pH}$ 6.5-7, dissolved oxygen above $10 \mathrm{mg} \cdot \mathrm{L}^{-1}$, ammonia below $1.0 \mathrm{mg} \cdot \mathrm{L}^{-1}$, nitrite below $1.0 \mathrm{mg} \cdot \mathrm{L}^{-1}$, chloride below $500 \mathrm{mg} \cdot \mathrm{L}^{-1}$, carbon dioxide below $5 \mathrm{mg} \cdot \mathrm{L}^{-1}$, water hardness between 100 and $300 \mathrm{mg} \cdot \mathrm{L}^{-1}$, and alkalinity between 40 and $300 \mathrm{mg} \cdot \mathrm{L}^{-1}$. If the levels fell outside of these recommendations, then a mitigation step was followed according to the parameter in question.

\subsection{Crops and Experimental Design}

Pelleted seeds of sweet basil (Ocimum basilicum 'Italian Large Leaf') and bibb lettuce (Lactuca sativa 'Rex') were obtained from Johnny's Selected Seeds (Winslow, ME, USA). For each species, a single pelleted seed was placed in a $3.8 \mathrm{~cm} \times 3.8 \mathrm{~cm}$ rockwool starter plug (Grodan A-OK; Farmtek, Dyersville, IA, USA) in numbers sufficient to supply the floating rafts (8 rafts per system) on a weekly basis 
for the duration of the study. Seedlings were irrigated daily with tap water supplemented with water-soluble fertilizer under the greenhouse conditions previously described. The 8 floating rafts were $60 \mathrm{~cm} \times 60 \mathrm{~cm} \times 3.8 \mathrm{~cm}$ and had either 9 (4 rafts) or 16 (4 rafts) holes on 20 or $15 \mathrm{~cm}$ spacings for lettuce or basil, respectively. Seedlings were transplanted 14 days after sowing into their appropriate rafts and inserted into the system at the distal end of the influent water from the biological filter (Figure 1). Each week, a new cohort of plants was germinated, and the next set of seedlings was transplanted into the system. The older plants were moved one space closer to the influent end of the floating raft hydroponic unit. Finally, after four weeks (28 days), the plants and roots were harvested from the system. This weekly cycle continued for the duration of this 118-day study based on a normal growth cycle for the barramundi fish.

\subsection{Microbiological Analysis}

Two heads of lettuce, or two bunches of basil, and $1 \mathrm{~L}$ of water was collected randomly from each of the six systems per sampling period (Days $0,28,42,54,63,76,88,102$, and 188). For lettuce, a random sample of $10 \mathrm{~g}$ was taken and added to $90 \mathrm{~mL}$ of $1 \%$ peptone (HiMedia, Mumbai, India) into a sterile stomacher bag. For basil, a random sample of $5 \mathrm{~g}$ was taken and added to $45 \mathrm{~mL}$ of $1 \%$ peptone and added to a sterile stomacher bag. For water, a random $10 \mathrm{~mL}$ sub sample was added to $90 \mathrm{~mL}$ of $1 \%$ peptone and added to a sterile stomacher bag. For the fish samples, swabs (Biomerieux, Marcy-l'Etoile, France) were taken on both sides of the body surface including gills and alimentary canals using a $10 \times 5 \mathrm{~cm}^{2}$ sterile template and added to $10 \mathrm{~mL}$ of a $1 \%$ peptone test tube. Individual samples were homogenized either in a stomacher or vortex and enumerated using coliform/E. coli Petrifilm ${ }^{\mathrm{TM}}$ (3M, St. Paul, MN, USA). Duplicate samples were used. Coliform and E. coli levels were enumerated using 3M Petrifilm E. coli/Coliform Count Plate ${ }^{\mathrm{TM}}$ (3M Microbiology Products, Minneapolis, MN, USA), following label directions (detection limit of $<10 \mathrm{CFU} \cdot \mathrm{g}^{-1} \mathrm{or}<1 \mathrm{CFU} \cdot \mathrm{mL}^{-1}$ or $<0.1 \mathrm{CFU} \cdot \mathrm{cm}^{-2}$ ). Plates were incubated at $35^{\circ} \mathrm{C}$ and observed for changes at 24 and $48 \mathrm{~h}$. Interpretation of the Petrifilm followed E. coli/Coliform Petrifilm label directions and AOAC Official Method 991.14. Blue to red-blue colonies associated with gas were counted as E. coli coliform colonies. Red colonies associated with gas were counted as coliform colonies. Further analysis was conducted on the samples for the presence of E. coli O157:H7 and Salmonella spp. using ELISA (color change assay) system $\left(3 \mathrm{M}^{\mathrm{TM}}\right.$ Tecra, St. Paul, MN, USA) and 0157 latex agglutination for confirmation (Oxoid/Remel, Hants, UK), as per manufacturer's instructions. Samples were processed through a series of enrichment and selection methods prior to the ELISA (detection limit: $1-5$ cells $/ 25 \mathrm{~g}$ of sample) test to reduce the presence of false positive samples. Twenty-five grams of lettuce and basil samples and $25 \mathrm{~mL}$ of water and fish swab samples were added to $225 \mathrm{~mL}$ of EC Broth ( $3 \mathrm{M}^{\mathrm{TM}}$ Tecra, Minneapolis, $\mathrm{MN}$, USA) with a $\%$ novobiocin supplement (MP, Salon, OH, USA) and incubated at $42 \pm 1{ }^{\circ} \mathrm{C}$ for $15-24 \mathrm{~h}$. This enrichment was used for ELISA analysis (E. coli 0157 detection). Same quantities of samples were incubated in $225 \mathrm{~mL}$ of Universal Pre-Enrichment Broth (DIFCO, Sparks, MD, USA) at $36{ }^{\circ} \mathrm{C}$ for $24 \mathrm{~h}$. Following incubation, $0.5 \mathrm{~mL}$ of sample was transferred into $10 \mathrm{~mL}$ of TT broth (Hajna) broth (DIFCO, Sparks, MD, USA) and $0.1 \mathrm{~mL}$ into $10 \mathrm{~mL}$ RV broth (DIFCO, Detroit, MI, USA) and incubated at $36 \pm 0.5^{\circ} \mathrm{C}$ for $22-24 \mathrm{~h}$. Following incubation, $1 \mathrm{~mL}$ of each were transferred to $10 \mathrm{~mL}$ of $\mathrm{M}$ Broth (HiMedia, Mumbai, India) and incubated at $36 \pm 0.5^{\circ} \mathrm{C}$ for $22-24 \mathrm{~h}$. This enrichment was used for ELISA analysis (Salmonella detection).

These rapid detection kits are approved by the U.S. Food and Drug Administration (FDA) for use on food samples. Aerobic plate counts were obtained in duplicate for each of the six systems, at suitable dilutions of BPW enrichment, incubated at $36^{\circ} \mathrm{C}$ for $48 \mathrm{~h}$, using media made from Total Plate Count Agar (HiMedia, Mumbai, India).

\subsection{Statistical Analysis}

This study was conducted between November 2014 and February 2015 and experiments were conducted in triplicate (3 UV and $3 \mathrm{No}-\mathrm{UV}$ (control)). Statistical analyses were performed using SAS 9.3 
(SAS Institute, Inc., Cary, NC, USA). Microbial counts were obtained for basil, lettuce, and water samples on Days 0, 28, 42, 54, 63, 76, 88, 102, and 118 in duplicate for each of the six UV/control systems, and data were analyzed using the least square means method. Direct swabs of fish (5 different fish from each unit) were taken on Days 0 and 118 in duplicate for microbial studies. The effects of the day and treatment were studied for aerobic plate counts and coliform counts. Combinatorial effects of the day and treatment were also studied. All statistical analyses were conducted at a $95 \%$ level of confidence $(p<0.05)$.

\section{Results}

Water quality parameters. The water quality parameters were recorded throughout the experiment and were as follows (means \pm SD): temperature: $23.2 \pm 5.2{ }^{\circ} \mathrm{C}$; dissolved oxygen: $8.1 \pm 1.0 \mathrm{mg} \cdot \mathrm{L}^{-1}$; $\mathrm{pH}: 7.7 \pm 1.0$; ammonia: $0.5 \pm 0.2 \mathrm{mg} \cdot \mathrm{L}^{-1}$; nitrite: $0.33 \pm 0.33 \mathrm{mg} \cdot \mathrm{L}^{-1}$; chloride: $250 \pm 100 \mathrm{mg} \cdot \mathrm{L}^{-1}$; carbon dioxide: $0.25 \pm 0.2 \mathrm{mg} \cdot \mathrm{L}^{-1}$; water hardness: $200 \pm 100 \mathrm{mg} \cdot \mathrm{L}^{-1}$; alkalinity: $104 \pm 4 \mathrm{mg} \cdot \mathrm{L}^{-1}$.

Pathogenic microbial status of the basil, lettuce, and water. There were no detectable levels of E. coli coliforms, E. coli O157:H7, or Salmonella spp. found in any of the lettuce, basil, or water samples over the 118-day study period.

Aerobic plate counts of the basil, lettuce, and water. Table 1 displays the aerobic plate counts in the basil, lettuce, and water samples over the 118-day study. There is a general trend of increasing aerobic plate counts ( 1 to $3 \log _{10} \mathrm{CFU} \cdot \mathrm{mL}^{-1}$ ) from Day 0 to Day 63 and a decrease in aerobic plate counts ( 1 to $3 \log _{10}$ CFU. $\mathrm{mL}^{-1}$ ) from Day 63 to Day 118 of the trial for the basil, lettuce, and water samples. There were no environmental changes between Day 0 and Day 63 samples, as determined by water temperatures and chemistry (ammonia, nitrite, nitrate, alkalinity, $\mathrm{pH}$, or dissolved oxygen levels, data not shown); therefore, these differences can be attributed to normal environmental flora variations.

Table 1. $\log _{10}$ of aerobic plate counts collected from basil, water, lettuce, and fish over 118 days in an aquaponic model system.

\begin{tabular}{|c|c|c|c|c|c|c|c|c|c|}
\hline \multirow{2}{*}{ Treatment } & \multicolumn{9}{|c|}{ Days of Sampling } \\
\hline & 0 & 28 & 42 & 54 & 63 & 76 & 88 & 102 & 118 \\
\hline \multicolumn{10}{|c|}{ Lettuce } \\
\hline NO UV & $4.97 \mathrm{Aa}$ & $4.80^{\mathrm{Aa}}$ & $3.78^{\mathrm{Aa}}$ & $5.37 \mathrm{Aa}$ & $6.17^{\mathrm{Ba}}$ & $5.52 \mathrm{Ca}$ & $4.21 \mathrm{Aa}$ & $4.32 \mathrm{Aa}$ & $2.87^{\mathrm{Aa}}$ \\
\hline UV & $5.32 \mathrm{Aa}$ & $4.51 \mathrm{Aa}$ & 3.81 Аа & $4.11^{\mathrm{Aa}}$ & $6.41^{\mathrm{Bb}}$ & $5.32 \mathrm{Aa}$ & $4.12^{\mathrm{Aa}}$ & $4.80^{\mathrm{Aa}}$ & $3.58^{\mathrm{Aa}}$ \\
\hline \multicolumn{10}{|c|}{ Basil } \\
\hline NO UV & $4.83^{\mathrm{Aa}}$ & $4.60 \mathrm{Aa}$ & $5.07 \mathrm{Aa}$ & $4.82 \mathrm{Aa}$ & $6.31 \mathrm{Aa}$ & $5.72 \mathrm{Aa}$ & $4.94 \mathrm{Aa}$ & $5.07 \mathrm{Aa}$ & $4.89 \mathrm{Aa}$ \\
\hline UV & $4.95 \mathrm{Aa}$ & $4.74 \mathrm{Aa}$ & $4.54^{\mathrm{Aa}}$ & 3.99 Аа & $6.23^{\mathrm{Aa}}$ & $5.74 \mathrm{Aa}$ & $4.83 \mathrm{Aa}$ & $4.96 \mathrm{Aa}$ & $4.69 \mathrm{Aa}$ \\
\hline \multicolumn{10}{|c|}{ Water } \\
\hline NO UV & $3.74^{\mathrm{Aa}}$ & $4.11 \mathrm{Aa}$ & 3.81 Аа & $4.40^{\mathrm{Aa}}$ & $6.07 \mathrm{Aa}$ & $5.80 \mathrm{Aa}$ & $5.45^{\mathrm{Aa}}$ & $4.63^{\mathrm{Aa}}$ & $4.05^{\mathrm{Aa}}$ \\
\hline UV & $3.78^{\mathrm{Aa}}$ & $4.38^{\mathrm{Aa}}$ & $4.32 \mathrm{Aa}$ & $4.46^{\mathrm{Aa}}$ & $6.19 \mathrm{Aa}$ & $5.81^{\mathrm{Aa}}$ & $5.24^{\mathrm{Aa}}$ & $4.42^{\mathrm{Aa}}$ & $4.33^{\mathrm{Aa}}$ \\
\hline \multicolumn{10}{|c|}{ Fish } \\
\hline NO UV & $4.97 \mathrm{Aa}$ & - & - & - & - & - & - & - & $5.57^{\mathrm{Ba}}$ \\
\hline UV & $4.97 \mathrm{Aa}$ & - & - & - & - & - & - & - & $5.04^{\mathrm{Ba}}$ \\
\hline
\end{tabular}

There was no significant difference between the UV and No-UV units for aerobic counts with the basil and water samples throughout the study $(p>0.05)$. There was a significant difference in the aerobic plate count in lettuce samples between the UV and No-UV treatments during the 118-day study $(p<0.05 ;$ Table 1$)$. Specifically, UV treatment had a significantly higher aerobic count $\left(0.24 \log _{10} \mathrm{CFU} \cdot \mathrm{g}^{-1}\right)$ for Day 63 than No-UV treatment. When the control treatment systems were 
evaluated alone, Day 63 showed a significantly higher in aerobic count $\left(0.65-3.30 \log _{10} \mathrm{CFU} \cdot \mathrm{g}^{-1}\right)$ than other days $(0,28,42,54,76,88,102$, or 118$)$, and Day 76 had a significantly higher aerobic count (1.74-2.65 $\log _{10}$ CFU.g ${ }^{-1}$ than Days 42 and 118. When the UV treatment systems were evaluated alone, Day 63 had a significantly higher aerobic count $\left(1.09-2.83 \log _{10}\right.$ CFU.g $\left.{ }^{-1}\right)$ than other days $(0,28,42,54$, $76,88,102$, or 118$)$.

When the UV and No-UV treatments were combined (Table 2), the lettuce samples had a significant increase in aerobic plate counts $\left(0.55-3.01 \log _{10} \mathrm{CFU} \cdot \mathrm{g}^{-1}\right.$ and $1.25-2.05 \log _{10} \mathrm{CFU} \cdot \mathrm{g}^{-1}$, respectively) between Days 54 and 76. There were no significant changes in the water quality for the basil or water samples when the UV and No-UV treatments were combined throughout the 118 days (data not shown).

Table 2. $\log _{10}$ of aerobic plate counts of the ultraviolet (UV) sterilizer and non-ultraviolet (No-UV) sterilized lettuce samples over the 118 days in an aquaponic model system.

\begin{tabular}{cccccccccc}
\hline Treatment/Day & $\mathbf{0}$ & $\mathbf{2 8}$ & $\mathbf{4 2}$ & $\mathbf{5 4}$ & $\mathbf{6 3}$ & $\mathbf{7 6}$ & $\mathbf{8 8}$ & $\mathbf{1 0 2}$ & $\mathbf{1 1 8}$ \\
\hline NO UV & $4.97^{\mathrm{Aa}}$ & $4.80^{\mathrm{Aa}}$ & $3.78^{\mathrm{Aa}}$ & $5.37^{\mathrm{Aa}}$ & $6.17^{\mathrm{Ba}}$ & $5.52 \mathrm{Ca}$ & $4.21^{\mathrm{Aa}}$ & $4.32^{\mathrm{Aa}}$ & $2.87 \mathrm{Aa}$ \\
UV & $5.32^{\mathrm{Aa}}$ & $4.51^{\mathrm{Aa}}$ & $3.81 \mathrm{Aa}$ & $4.11^{\mathrm{Aa}}$ & $6.41^{\mathrm{Bb}}$ & $5.32^{\mathrm{Aa}}$ & $4.12^{\mathrm{Aa}}$ & $4.80 \mathrm{Aa}$ & $3.58 \mathrm{Aa}$ \\
\hline
\end{tabular}

Notes: ${ }^{\mathrm{A}, \mathrm{B}, \mathrm{C}}$ Different letters indicate significant differences $(p<0.05)$ within the same row; ${ }^{\mathrm{a}, \mathrm{b}}$ Different letters indicate significant differences $(p<0.05)$ within the same column.

Coliform counts of the basil, lettuce, and water. There was no significant difference between the UV and No-UV units in general for coliform counts in general (lettuce, basil, and water samples) $(p>0.05)$. Table 3 displays the coliform counts for the basil, lettuce, and water samples over the 118-day study. There was a significant increase in coliform counts $\left(0.61-2.12 \log _{10} \mathrm{CFU} \cdot \mathrm{g}^{-1}\right)$ observed in all the samples (basil, lettuce, and water) on Day 28 of the trial when compared to all the other days. There was a significant decrease $\left(0.24-1.87 \log _{10} \mathrm{CFU} \cdot \mathrm{g}^{-1}\right)$ in the coliform counts in all samples on Day 76 when compared with Days 28, 42, and $54(p<0.05)$, which had a significant increase in coliform counts $\left(0.50-1.78 \log _{10} \mathrm{CFU} \cdot \mathrm{g}^{-1}\right)$ on Day 88 for all the samples. With the water sample, there was a significant decrease in coliform counts (1.13-1.67 $\log _{10}$ CFU. $g^{-1}$ ) between Days 88 and 118 of the trial in the presence and absence of UV treatment. It must be noted that there were no significant temperature or environmental changes on Day 76 during the study; therefore, these differences can be attributed to normal environmental flora variations.

Table 3. $\log _{10}$ of coliform counts collected from basil, water, lettuce, and fish over 118 days in an aquaponic model system.

\begin{tabular}{|c|c|c|c|c|c|c|c|c|c|}
\hline \multirow{2}{*}{ Treatment } & \multicolumn{9}{|c|}{ Days of Sampling } \\
\hline & 0 & 28 & 42 & 54 & 63 & 76 & 88 & 102 & 118 \\
\hline \multicolumn{10}{|c|}{ Lettuce } \\
\hline NO UV & $1.45^{\mathrm{Aa}}$ & $2.03^{\mathrm{Ba}}$ & $1.60^{\mathrm{Aa}}$ & $1.83^{\mathrm{Aa}}$ & $0.98^{\mathrm{Aa}}$ & $0.45^{\mathrm{Ca}}$ & $1.59 \mathrm{Aa}$ & $0.70^{\mathrm{Aa}}$ & $0.12^{\mathrm{Da}}$ \\
\hline UV & $1.42^{\mathrm{Aa}}$ & $1.07^{\mathrm{Ba}}$ & $1.68^{\mathrm{Aa}}$ & $1.76^{\mathrm{Aa}}$ & $0.85^{\mathrm{Aa}}$ & $0.30^{\mathrm{Ca}}$ & $1.70^{\mathrm{Aa}}$ & $1.52^{\mathrm{Aa}}$ & $0.95^{\mathrm{Da}}$ \\
\hline \multicolumn{10}{|c|}{ Basil } \\
\hline NO UV & $0.07 \mathrm{Aa}$ & $1.95 \mathrm{Ba}$ & $1.85^{\mathrm{Ba}}$ & $1.83^{\mathrm{Ba}}$ & $1.19^{\mathrm{Ba}}$ & $0.26^{\mathrm{Ca}}$ & $1.65^{\mathrm{Ba}}$ & $1.54^{\mathrm{Ba}}$ & $1.68^{\mathrm{Ba}}$ \\
\hline UV & $0.18^{\mathrm{Aa}}$ & $2.14^{\mathrm{Ba}}$ & $1.60^{\mathrm{Ba}}$ & $2.06^{\mathrm{Ba}}$ & $1.43^{\mathrm{Ba}}$ & $0.52^{\mathrm{Ca}}$ & $1.54^{\mathrm{Ba}}$ & $1.77 \mathrm{Ba}$ & $1.79 \mathrm{Ba}$ \\
\hline \multicolumn{10}{|c|}{ Water } \\
\hline NO UV & $1.00^{\mathrm{Aa}}$ & $2.26^{\mathrm{Ba}}$ & $2.11^{\mathrm{Ba}}$ & $2.11^{\mathrm{Ba}}$ & $1.30^{\mathrm{Ba}}$ & $0.12^{\mathrm{Ca}}$ & $2.12^{\mathrm{Ba}}$ & $1.30^{\mathrm{Ba}}$ & $2.21^{\mathrm{Ba}}$ \\
\hline UV & $0.98 \mathrm{Aa}$ & $2.09 \mathrm{Ba}$ & $2.14^{\mathrm{Ba}}$ & $1.90^{\mathrm{Ba}}$ & $1.38^{\mathrm{Ba}}$ & $0.45^{\mathrm{Ca}}$ & $2.06^{\mathrm{Ba}}$ & $1.62 \mathrm{Ba}$ & $1.68^{\mathrm{Ba}}$ \\
\hline \multicolumn{10}{|c|}{ Fish } \\
\hline NO UV & $1.17 \mathrm{Aa}$ & - & - & - & - & - & - & - & $1.50^{\mathrm{Aa}}$ \\
\hline UV & $1.17^{\mathrm{Aa}}$ & - & - & - & - & - & - & - & $1.85^{\mathrm{Aa}}$ \\
\hline
\end{tabular}

Notes: ${ }^{A, B, C, D}$ Different letters indicate significant differences $(p<0.05)$ within the same row for a given product;

a Different letters indicate significant differences $(p<0.05)$ within the same column for a given product. 
Microbial status of fish. There were no E. coli coliforms, E. coli O157:H7, or Salmonella spp. found in any of fish samples over the 118-day study period. Tables 1 and 3 display the aerobic plate counts and coliform counts for the barramundi fish on Days 0 and 118 of the trial. There was a significant increase of aerobic counts $\left(0.65 \log _{10} \mathrm{CFU} \cdot \mathrm{g}^{-1}\right)$ in the fish sample with the presence and absence of UV on Days 0 and $118(p>0.05)$. There was no significant increase or decrease in the coliform counts on Days 0 and 118 in the presence or absence of UV treatments. Aerobic plate counts above $10^{7} \mathrm{CFU} \cdot \mathrm{g}^{-1}$ are seen as unacceptable for fish and produce [16]. Fecal coliforms (E. coli) above $500 \mathrm{CFU} \cdot \mathrm{g}^{-1}$ in fish and produce are also seen as unacceptable [16]. Fecal coliforms are an indicator of poor water supply and poor sanitation practices [17]. Within this study, our counts remained below the APC, coliform, and fecal coliform limit, indicating our system had good sanitation conditions and the food is safe for consumption, but the high variability in the microbial counts requires additional research to solidify the theory of normalization in the system.

\section{Discussion}

If zoonotic pathogens were introduced into the system, the risk for foodborne illness from the fish and/or food crop would be higher [18]. There have been multiple foodborne outbreaks with E. coli and Salmonella associated with fruits and vegetables that have been attributed to water sources [19]. Absences of these pathogens within this study indicate that they were not externally introduced into the system, highlighting good hygiene and sanitation practices throughout the study. Effective usage of UV treatment has been suggested to reduce the abundance of many bacterial pathogens suspended in water in aquaponic operations, and thus reduce the probability of cross contamination between water and plant tissue [13,20-22]. Gonazalez-Alanis (2011) found that use of UV within the aquaponics system with lettuce, spinach, and tilapia was able to reduce fecal and total coliforms significantly (UV levels was not provided) [23]. Our results show high variation in the aerobic plate counts and coliform counts and that UV was not effective at reducing both aerobic and coliform counts on the lettuce, basil, water, and fish samples when compared to the control system (Tables 1-3). So why was our treatment not effective in our system? Potential answers include the addition of filtration/screening, the reduction in microbial community within the system, and the use of higher intensity UV units.

Timmons and Ebeling (2007) suggest that the water should be filtered through a $50 \mu \mathrm{m}$ screen prior to exposure to UV irradiation to improve UV efficacy in a recirculating aquaculture system [4]. Within this model system, there was no filtration system at $50 \mu \mathrm{m}$ because our preliminary data showed that our flow rate and water utilization provided clearer (turbidity) water (1-2.5 NTUs) than the use of a $50 \mu \mathrm{m}$ screen (typically 20 NTUs). Even with our low turbidity levels in the water entering the UV unit, the use of filtration may help with the effectiveness of the UV technology. Pantanella (2012) found that the use of two commercial $25 \mathrm{~W}$ lamps of ultraviolet light (UV) sterilizers with a $100 \mathrm{~L}$ clarifier and $25 \mathrm{~L}$ filtering tank within an aquaponics system with lettuce and tilapia was effective in reducing coliform by 3 logs; however, depending on the water quality, different UV intensities are needed [24]. UV systems with a light output as high as $36 \mathrm{~W}$ have been used in recirculating aquaculture systems [25]. Our unit was only at a $15 \mathrm{~W}$ light output based on the manufacturer's recommendation for a flow rate of $20.8 \mathrm{~L} \cdot \mathrm{min}^{-1}$ and the stability of nutrients in the system. Flocculation and chemical precipitation using lime, alum, or ferric chloride, the method most commonly used by municipalities can be extended to aquaponics if modified for living systems [26]. This method could clarify the circulating water allowing for deeper penetration of UV rays, but these substances would need to be monitored to ensure that the change in $\mathrm{pH}$ would not affect the plants or fish units through additional research. The last potential answer is in regard to microbial community within the aquaponics units. Our system had a general trend of microbial increase within the study period followed by a decrease after 76 days (Tables 2 and 3). We attribute the fluctuation pattern within both the hydroponic and aquaponic units to normal microbial community changes. Schreier, Mirzoyan, and Saito (2010) explain that the biological filtration systems rely on the interaction between microbial 
communities, and their environment, as a consequence of nutrient input (fish waste output) and, as such, are not easily controlled [27]. The inconsistent patterns and variability between and amongst treatments observed in the microbial counts in our study is likely due to these dynamic ecosystem interactions that occur in a living system like aquaponics. The biosolids and rich microbial community within aquaponic units was critical to producing the ideal growing conditions for both crops and fish. If these biosolids and microbial communities are disrupted, poor growth rates and a lack of nutrients for crops and fish may result [28]. Additionally, a recirculating aquaculture system's water management is critical to ensure the health of fish and/or continuous crop production [28]. To maintain homogeneity, a greater understanding of the life support processes that make up the biological filtration systems is required. High microbial populations within the water may be interfering with the effectiveness of the UV technology.

The original aquaponic model was based on a "balanced" or "coupled" style aquaponic system. This model uses a single direction of water flow from the fish, through the filters, through the plants, and back to the fish. This model necessitates a balance of nutrients and the elimination of pesticides and therapeutants in order to promote the fish, plants, and beneficial bacteria that are critical to system functionality. Thus, it was prudent in the design of these systems to install some relatively innocuous, yet proven effective, form of water sterilization. Because there had been no replicated research on small-scale aquaponic systems available in the literature prior to this project's inception, design constraints were derived from the closest known field of research-aquaculture. In recirculating aquaculture system design, it is common to place the UV sterilizer into the system after the mechanical and biological filters, the sump, and the water pump, and immediately before the water enters the fish culture tank. That is the design principle that was used in the creation of these systems. The UV sterilizer was operated as close to the manufacturer's specifications as possible given the nuances of the prototype systems that were designed specifically for this study.

Research conducted in parallel to the timeline of this experiment has given insight to the proper design of an aquaponics system. Personal communications with Sarah Taber (Aquaponics Association, 30 November 2016) revealed that much of the food safety risk for humans is located in the hydroponic component of the system. Much of the bacterial growth in a deep water culture unit is located on the plant roots that are suspended in the water, according to Taber (personal communication). Improved filtration of the water for greater water clarity as well as more powerful UV sterilizers could be employed.

The delicate nature of a balanced system creates challenges for aquaponic producers; therefore, other methods of aquaponic operation have been created. The more robust "decoupled" aquaponic design segregated fish and plant production systems (aquaculture and hydroponics, respectively) and allowed more flexibility for the producer to treat the fish and plants separately without causing harm to other components of the system. Since the time of this research, the systems have been adapted to improve solid settling by installing a radial flow settling chamber. The systems have been successfully used to grow plants hydroponically, but have not yet contained fish. Fine-tuning water flow rates and flow dynamics of the system is a priority for avoiding potential water clarity issues. Potential system designs that could be used in future iterations include a decoupled concept, in which the water discharged from the recirculating aquaculture system during routine filter cleaning could flow one direction into a sump that would be pumped to the hydroponic unit where it is fully utilized by the plants and never returned to the aquaculture unit. This practice would allow the installation of a more powerful sterilization method (e.g., ozone, hydrogen peroxide, peracetic acid, and sodium hypochlorite) to completely kill all life before the water reaches the plants, thus improving food safety. Another option could be to install the UV sterilizer between the biological filter and the hydroponic unit, or have multiple UV units at different points in the system.

This study found that the UV treatment used in our model aquaponic unit was not effective in reducing coliform and aerobic plate counts. Clarification of the water or reducing the flow rate might improve the penetration of UV or increasing the intensity of the radiation may control microbial populations to a greater extent. Future studies can be conducted to determine the relationship between 
turbidity and smaller filters, microbial density, and the intensity of the UV to improve the ability of this technology to be used as a food safety intervention.

Acknowledgments: Help from the Leopold Center for Sustainable Agriculture is greatly appreciated.

Author Contributions: Angela M. Shaw, D. Allen Pattillo, Christopher J. Currey and Kurt A. Rosentrater conceived and designed the experiment and secured funding for the experiment. D. Allen Pattillo was the lead of the fish side of the experiment, Christopher J. Currey was the lead of the plant side of the experience, while Angela M. Shaw led the food safety attribution. Sai Deepikaa Elumalai and Kun Xie were the students who performed the daily tasks of the research (data collection). Angela M. Shaw and Sai Deepikaa Elumalai analyzed the data and wrote the paper. Kurt A. Rosentrater trained the students on the analysis tools and assisted with the review of the manuscript.

Conflicts of Interest: The authors declare no conflict of interest.

\section{Abbreviations}

The following abbreviations are used in this manuscript:

$\begin{array}{ll}\text { CFU } \cdot \mathrm{cm}^{-2} & \text { colony forming units per square centimeter } \\ \mathrm{CFU} \cdot \mathrm{mL}^{-1} & \text { colony forming units per milliliter } \\ \mathrm{CFU} \cdot \mathrm{g}^{-1} & \text { colony forming units per gram } \\ \mathrm{cm} & \text { centimeter } \\ \mathrm{g} & \text { gram } \\ \mathrm{h} & \text { hour } \\ \mathrm{HDPE} & \text { high-density polyethylene } \\ \mathrm{kg} & \text { kilogram } \\ \mathrm{L} & \text { liter } \\ \mathrm{lm} & \text { lumen } \\ \mathrm{L} \cdot \mathrm{min}^{-1} & \text { liters per minute } \\ \mathrm{L} \cdot \mathrm{h}^{-1} & \text { liters per hour } \\ \mathrm{m} & \text { meter } \\ \mathrm{mg} & \text { milligram } \\ \mathrm{min} & \text { minute } \\ \mathrm{mL} & \text { milliliter } \\ \mathrm{mm} & \text { millimeter } \\ \mathrm{PVC} & \text { polyvinyl chloride } \\ \mathrm{UV} & \text { ultraviolet } \\ \mathrm{W} & \text { Watt }\end{array}$

\section{References}

1. Economic Research Service. Trends in U.S. Local and Regional Food Systems: Report to Congress; Administrative Publication Number 068; USDA: Washington, DC, USA. Available online: https://www.ers.usda.gov/ webdocs/publications/ap068/51174_ap068_report-summary.pdf (accessed on 3 January 2017).

2. Khater, E.-S.G.; Ali, S.A. Effect of flow rate and length of gully on lettuce plants in aquaponic and hydroponic systems. J. Aquac. Res. Dev. 2015, 6, 348-354.

3. Palm, H.W.; Nievel, M.; Knaus, U. Significant factors affecting the economic sustainability of closed aquaponic systems. Part III: Plant units. AACL Bioflux 2015, 8, 89-106.

4. Timmons, M.; Ebeling, J. Recirculating Aquaculture; Nrac Publication No. 01-007; Cayuga Aqua Ventures: Ithaca, NY, USA, 2007; p. 975.

5. Palm, H.W.; Bissa, K.; Knaus, U. Significant factors affecting the economic sustainability of closed aquaponic systems. Part II: Fish and plant growth. AACL Bioflux 2014, 7, 162-175.

6. Painter, J.A.; Hoekstra, R.M.; Ayers, T.; Tauxe, R.V.; Braden, C.R.; Angulo, F.J.; Griffin, P.M. Attribution of foodborne illnesses, hospitalizations, and deaths to food commodities by using outbreak data, United States, 1998-2008. Emerg. Infect. Dis. 2013, 19, 407-415. [CrossRef] [PubMed]

7. Nesse, L.; Lovold, T.; Bergsj, B.; Nordby, K.; Wallace, C.; Holstad, G. Persistence of orally administered Salmonella enterica serovars Agona and Montevideo in Atlantic salmon (Salmo salar L.). J. Food Prot. 2005, 68, 1336-1339. [CrossRef] [PubMed]

8. Pal, D.; Dasgupta, C. Nonspecific defense-mechanisms of Cirrhinus mrigala against Escherichia coli and Salmonella typhi. Curr. Sci. India 1992, 63, 744-747. 
9. Fox, B.K.; Tamaru, C.S.; Hollyer, J.; Castro, L.F.; Fonseca, J.M.; Jay-Russell, M.; Low, T. A preliminary study of microbial water quality related to food safety in recirculating aquaponic fish and vegetable production systems. Food Saf. Technol. 2012, 51,1-11.

10. Pantanella, E.; Cardarelli, M.; di Mattia, E.; Colla, G. Aquaponics and food safety: Effects of UV sterilization on total coliforms and lettuce production. Acta Hortic. 2010, 1062, 71-76. [CrossRef]

11. Kim, J.-G.; Yousef, A.E.; Khadre, M.A. Ozone and its current and future application in the food industry. Adv. Food Nutr. Res. 2003, 45, 167-218. [PubMed]

12. Sirsat, S.A.; Neal, J.A. Microbial profile of soil-free versus in-soil grown lettuce and intervention methodologies to combat pathogen surrogates and spoilage microorganisms on lettuce. Foods 2013, 2, 488-498. [CrossRef]

13. Guerrero-Beltr, J.; Barbosa-C, G.V. Advantages and limitations on processing foods by UV light. Food Sci. Technol. Int. 2004, 10, 137-147. [CrossRef]

14. Chang, J.C.; Ossoff, S.F.; Lobe, D.C.; Dorfman, M.H.; Dumais, C.M.; Qualls, R.G.; Johnson, J.D. UV inactivation of pathogenic and indicator microorganisms. Appl. Environ. Microbiol. 1985, 49, 1361-1365. [PubMed]

15. Timmons, M.; Ebeling, J. Recirculating Aquaculture, 3rd ed.; Ithaca Publishing Company: Ithaca, NY, USA, 2013; pp. 687-688.

16. International Commission on Microbiological Specifications for Foods (ICMSF). Microorganisms in Foods: 181. Available online: http:/ /www.icmsf.org/pdf/icmsf2.pdf (accessed on 4 November 2015).

17. Varga, S.; Anderson, G. Significance of coliforms and enterococci in fish products. Appl. Microbiol. 1968, 16, 193-196. [PubMed]

18. Hollyer, J.; Tamaru, C.; Riggs, A.; Klinger-Bowen, R.; Howerton, R.; Okimoto, D.; Castro, L.; Ron, T.B.; Fox, B.K.; Troegner, V. On-farm food safety: Aquaponics. Food Saf. Technol. 2009, 38, 1-7.

19. Centers for Disease Control and Prevention (CDC). Surveillance for Foodborne Disease Outbreaks-United States, 1998-2008; Annual Report; U.S. Department of Health and Human Services, CDC: Atlanta, GA, USA, 2013. Available online: https://www.cdc.gov/mmwr/preview/mmwrhtml/ss6202a1.htm (accessed on 3 January 2017).

20. Bintsis, T.; Litopoulou-Tzanetaki, E.; Robinson, R.K. Existing and potential applications of ultraviolet light in the food industry-A critical review. J. Sci. Food Agric. 2000, 80, 637-645. [CrossRef]

21. Friedberg, E.C.; Walker, G.C.; Siede, W.; Wood, R.D. DNA Damage. In DNA Repair and Mutagenesis; American Society for Microbiology Press: Washington, DC, USA, 2005.

22. Moeller, R.; Douki, T.; Cadet, J.; Stackebrandt, E.; Nicholson, W.L.; Rettberg, P.; Reitz, G.; Horneck, G. UV-radiation-induced formation of DNA bipyrimidine photoproducts in Bacillus subtilis endospores and their repair during germination. Int. Microbiol. 2010, 10, 39-46.

23. González-Alanis, P.; Gutierrez-Olguín, J.I.; Castro-Segura, I.; Ezqueda-Palacios, H.; Gojon-Báez, H.H.; Aguirre-Guzmán, G.; Guzmán-Saénz, F.M.; Fitzsimmons, K.M. Food Safety Study of Leafy Green Irrigated with Tilapia Farm Effluents in Tamaulipas. Available online: http:/ /cals.arizona.edu/azaqua/ista/ISTA9/ Book/ISTA\%209\%20Publications-1st.pdf\#page=121 (accessed on 3 January 2017).

24. Pantanella, E. Nutrition and Quality of Aquaponic Systems; Università Degli Studi Della Tuscia: Viterbo, Italy, 2012; pp. 46-54.

25. Petrea, S.M.; Cristea, V.; Dediu, L.; Contoman, M.; Lupoae, P.; Mocanu, M.C.; Coada, M.T. Vegetable production in an integrated aquaponic system with rainbow trout and spinach. Bull. Univ. Agric. Sci. 2013, 70, 45-54.

26. Adler, P.R.; Harper, J.K.; Takeda, F.; Wade, E.M.; Summerfelt, S.T. Economic evaluation of hydroponics and other treatment options for phosphorus removal in aquaculture effluent. HortScience 2000, 35, 993-999.

27. Schreier, H.J.; Mirzoyan, N.; Saito, K. Microbial diversity of biological filters in recirculating aquaculture systems. Curr. Opin. Biotechnol. 2010, 21, 318-325. [CrossRef] [PubMed]

28. Rakocy, J.E.; Masser, M.P.; Losordo, T.M. Recirculating Aquaculture Tank Production Systems: Aquaponics-Integrating Fish and Plant Culture. SRAC Publ. 2006, 454, 1-6.

(C) 2017 by the authors; licensee MDPI, Basel, Switzerland. This article is an open access article distributed under the terms and conditions of the Creative Commons Attribution (CC-BY) license (http://creativecommons.org/licenses/by/4.0/). 